\section{CHARACTER EDUCATION LEARNING FOR RESIDENT LEARN PACKAGE C AT PKBM}

\author{
PEMBELAJARAN PENDIDIKAN \\ KARAKTER BAGI \\ WARGA BELAJAR PAKET C DI PKBM
}

Jurnal Pendidikan Luar Sekolah

http://kolokium.ppj.unp.ac.id/

Jurusan Pendidikan Luar Sekolah

Fakultas Ilmu Pendidikan

Universitas Negeri Padang

Sumatera Barat, Indonesia

Volume 9, Nomor 1, 2021

DOI: 10.24036/kolokium-pls.v9i1.457

Received 15 Maret 2021

Approved 10 April 2021

Published 22 April 2021

\author{
Ariq Rahmanianto ${ }^{1}$ \\ ${ }^{1}$ Universitas Singaperbangsa Karawang \\ 2rahmanianto18@gmail.com
}

\begin{abstract}
The purpose of this study was to (1) describe the process of learning character education for residents learning package $\mathrm{C}$ at pkbm Aditya. (2) Describe the implementation of the main character values in character education learning for residents learning package $C$ at pkbm Aditya. (3) Describe the supporting and inhibiting factors of character education learning for residents learning package $\mathrm{C}$ at pkbm Aditya. This study uses a qualitative approach with descriptive qualitative methods. The study was carried out in the Street Child Care Education Community in the City of Bekasi. The research subjects are: (1) Informant sources: one manager and one volunteer, (2) Information sources: two learning residents. Data collection techniques using observation, interviews, documentation. The stages of research carried out are orientation, exploration, and member check. Data analysis uses data collection, data reduction, data presentation, and verification conclusions. The results of this study indicate that (1) The process begins with compiling various learning plans, sorting out what character values will be applied. Character education is poured into learning activities so that students are unconsciously implementing it. (2) In implementing the main values of the PBM characters, Aditya is able to run it well, it can be seenfrom the 5maincharacter values that everythingcanbe implemented.(3)Supporting and inhibiting factors in character education learning are the spirit of student motivation to become better individuals, but parental involvement is still lacking because not all parents can always guide and monitor their children's activities at home.
\end{abstract}

Keywords: Learning, Character Education, PKBM

\begin{abstract}
ABSTRAK
Tujuan penelitian ini adalah untuk (1) mendeskripsikan proses pembelajaran pendidikan karakter bagi warga belajar paket C di pkbm Aditya. (2) Mendeskripsikan implementasi nilai-nilai karakter utama dalam pembelajaran pendidikan karakter bagi warga belajar paket $\mathrm{C}$ di pkbm Aditya. (3) Mendeskripsikan faktor pendukung dan penghambat pembelajaran pendidikan karakter bagi warga belajar paket $\mathrm{C}$ di pkbm Aditya. Penelitian ini menggunakan pendekatan kualitatif dengan metode deskriptif kualitatif. Penelitian dilakukan di Komunitas Pendidikan Pengasuhan Anak Jalanan Kota Bekasi. Subyek penelitian adalah: (1) Sumber informan: satu pengelola dan satu relawan, (2) Sumber informasi: dua warga belajar. Teknik pengumpulan data menggunakan observasi, wawancara, dokumentasi. Tahapan penelitian yang dilakukan adalah orientasi, eksplorasi, dan member check. Analisis data menggunakan pengumpulan data, reduksi data, penyajian data, dan verifikasi kesimpulan. Hasil penelitian ini menunjukkan bahwa (1) Proses dimulai dengan menyusun berbagai rencana
\end{abstract}


pembelajaran, memilah nilai-nilai karakter apa yang akan diterapkan. Pendidikan karakter dituangkan ke dalam kegiatan pembelajaran sehingga siswa secara tidak sadar mengimplementasikannya. (2) Dalam mengimplementasikan nilai-nilai utama karakter PBM, Aditya mampu menjalankannya dengan baik, hal ini terlihat dari 5 nilai karakter utama yang semuanya dapat diterapkan. (3) Faktor pendukung dan penghambat dalam pembelajaran pendidikan karakter adalah semangat motivasi siswa untuk menjadi individu yang lebih baik, namun keterlibatan orang tua masih kurang karena tidak semua orang tua dapat selalu membimbing dan memantau aktivitas anaknya di rumah.

Kata Kunci: Pembelajaran, Pendidikan Karakter, PKBM

\section{PENDAHULUAN}

Pendidikan Karakter adalah suatu sistem penanaman nilai-nilai karakter kepada warga sekolah yang meliputi komponen pengetahuan, kesadaran atau kemauan, dan tindakan untuk melaksanakan nilai-nilai tersebut. Dalam pendidikan karakter, semua komponen (pemangku pendidikan) harus dilibatkan, termasuk komponen-komponen pendidikan itu sendiri, yaitu isi kurikulum, proses pembelajaran dan penilaian, penanganan atau pengelolaan mata pelajaran, pengelolaan, pelaksanaan aktivitas, pemberdayaan sarana prasarana, pembiayaan, dan ethos kerja seluruh warga belajar/lingkungan. Di samping itu, pendidikan karakter dimaknai sebagai suatu perilaku warga belajar yang dalam menyelenggarakan pendidikan harus berkarakter. Dalam UU No.20 Tahun 2003 pasal 13 tentang Sistem Pendidikan Nasional, pendidikan dapat bersifat formal, nonformal dan informal. Salah satu satuan pendidikan non formal yang memiliki posisi strategis dalam menyelenggarakan program pendidikan karakter adalah Pusat Kegiatan Belajar Masyarakat (PKBM), Paket C merupakan bagian dari program PKBM yang setara dengan SMA. Program ini dikembangkan mengingat banyaknya masyarakat lulusan SMP yang tidak melanjutkan serta putus sekolah saat SMA, dan usia produktif yang ingin mengembangkan diri dalam kecakapan hidup sehingga perlu diadakan pola pelayanan yang dapat memberikan kepada mereka untuk siap memasuki dunia kerja atau melanjutkan ke jenjang yang lebih tinggi.

PKBM Aditya, PKBM yang berlokasi di jalan A.Yani (By-Pass) Gg. Betet No.33 Karangpawitan Kec. Karawang Barat Kab. Karawang Jawa Barat. Merupakan salah satu lembaga non formal yang mengelola pembelajaran paket C. Sasaran dari program tersebut tidak dibatasi oleh usia siapa saja boleh menjadi warga belajarnya. Mereka terdiri dari berbagai macam kepribadian berbeda. Dalam pelaksanaan nya tidak terlepas dari nilai-nilai pendidikan karakter yang diharapkan nantinya dapat mengubah dan memperbaiki sikap sasaran warga belajar tersebut. Untuk memulai suatu proses pembelajaran karakter diperlukan yang namanya perencanaan, pelaksanaan, dan penilaian. Perencanaan terdiri dari silabus, RPP, dan bahan ajar yang dirancang agar muatan maupun kegiatan pembelajarannya memfasilitasi atau berwawasan pendidikan karakter. Cara yang mudah untuk membuat perencanaan pembelajaran yang berwawasan pendidikan karakter adalah dengan mengadaptasi silabus, RPP, dan bahan ajar yang telah dibuat atau ada. Pada tahap pelaksanaan, tutor harus mampu memilih pendekatan yang sesuai untuk menyampaikan pendidikan karakter. Pada tahap penilaian harus didasarkan pada indikator yang sudah ditentukan. Beberapa penelitian tentang karakter salah satu nya yang dilakukan oleh Alprilia (2016) yang berjudul "Penerapan pendidikan karakter bagi masyarakat marjinal". Hasil dari penelitian tersebut adanya penerapan pendidikan karakter yang dilakukan melalui beberapakegiatan, kendalayang dihadapi ketikamenerapkan nilai-nilai karakter yaitu masih sulitnya bagaimana cara yang efektif untuk mengubah pola pikir warga belajarnya. Dari hasil tersebut dapat di simpulkan 
Character Education Learning for Resident Learn Package C...

bahwa masih adanya kendala di lapangan dalam melaksanakan pembelajaran pendidikan karakter.

\section{METODE}

Penelitian ini menggunakan pendekatan kualitatif dengan metode deskriptif. Penelitian ini difokuskan kepada suatu analisis tertentu untuk mengungkapkan kenyataan yang terjadi di lapangan untuk dipahami secara mendalam, sehingga diperoleh data yang diperlukan untuk tujuan penelitian. Secara umum penelitian bertujuan untuk mengetahui proses, impelementasi, faktor pendukung dan penghambat. Adapun subjek yang diteliti dalam penelitian ini yaitu pengelolaPKBM Aditya Karawang, seorang tutor dan tigaorang siswa yang dapat memberikan informasi tentang proses, implementasi, faktor pendukung dan penghambat pendidikan karakter. Dengan teknik pengumpulan data yaitu observasi, wawancara, dan dokumentasi. Teknik analisis data yang digunakan dalam penelitian ini adalah analysis interactive model dari Miles dan Huberman, yang membagi langkah-langkah dalam kegiatan analisis data dengan beberapa bagian yaitu pengumpulan data, reduksi data, display data, kesimpulan dan verifikasi.

\section{PEMBAHASAN}

Alasan PKBM Aditya memasukkan pendidikan karakter didasari oleh ingin nya menciptakan generasi yang baik dari segi sikap dan perilaku yang dapat menjadi pembeda dengan yang lain nya. Hal ini senada dengan pendapat Muchlas samani (2017: 43) " Karakter dapat dimaknai sebagai nilai dasar yang membangun pribadi seseorang, terbentuk baik karena pengaruh hereditas maupun pengaruh lingkungan yang membedakannya dengan orang lain, serta diwujudkan dalam sikap dan perilakunya dalam kehidupan sehari-hari “. Dalam proses nya, PKBM Aditya membuat perencanaan pendidikan karakter dengan memasukkan nya kedalam modul pembelajaran silabus/rpp.

Adapun bahan ajar yang disediakan oleh PKBM Aditya terdiri dari beberapa sumber salah satunya buku kejar paket c yang disediakan oleh dinas pendidikan. Hal tersebut sesuai dengan Kementrian Pendidikan Nasional tahun 2011 "Program pendidikan karakter secara dokumen terintegrasi kedalam kurikulum tingkat satuan pendidikan (KTSP) mulai dari visi, misi, tujuan, struktur dan muatan kurikulum, kalender pendidikan, silabus, rencana pelaksanaan pembelajaran (RPP)". Dari 18 nilai karakter bangsa, Nilai karakter yang akan ditanamkan kepada warga belajar paket C PKBM Aditya Karawang hanya beberapa saja yaitu nilai Religi, disiplin, kreatif, toleransi, dan juga peduli sosial. Alasan dipilihnya beberapa nilai karakter tersebut adalah mengingat waktu belajar sedikit dan kemampuan siswa yang terbatas.

Dalam melaksanakan penanaman nilai-nilai karakter, tutor di PKBM Aditya Karawang memiliki peran penting. Mereka melakukan kegiatan pembelajaran semaksimal mungkin agar siswa tidak hanya memiliki pengetahuan tentang materi yang disampaikan namun juga mampu mengimplementasikan nilai-nilai karakter yang sudah diberikan. Tutor menggunakan berbagai metode dengan tujuan siswa paham dengan materi yang disampaikan. Metode yang digunakan adalah metode yang berpusat pada siswa seperti diskusi. Penanaman karakter pun berlaku pada saat diluar kegiatan kelas seperti adanya kegiatan tambahan berwirausaha dan ekstrakurikuler pramuka, Hal ini sesuai dengan yang diungkapkan Heri Gunawan (2012: 224) menyatakan bahwa, pendidikan karakter secara terintegrasi didalam mata pembelajaran adalah pengenalan nilai-nilai, diperolehnya kesadaran akan pentingnya 
nilai-nilai, dan penginternalisasian nilai-nilai kedalam tingkah laku peserta didik sehari-hari melalui proses pembelajaran, baik yang berlangsung di dalam maupun di luar kelas pada semua mata pelajaran.

Dalam tahap evaluasi PKBM Aditya melakukan observasi atau pengamatan, tidak ada tes khusus ataupun tertulis. Tutor menyusun lembar pengamatan yang nantinya digunakan untuk menilai seberapabaik siswamenunjukkan sikap yang mencerminkan nilainilai karakter. Untuk waktunya dilakukan setiap saat, dimulai siswa itu memasuki kelas hingga selesai pembelajaran. Sistem penilaian pendidikan karakter tidak menggunakan sistem skor, namun menggunakan pernyataan kualitatif. Sistem penilaian tersebut diaplikasikan untuk mengembangkan kepribadian peserta. Penilaian didasari pada indikator yang telah ditentukan, seperti misalnya indikator untuk nilai jujur atau kejujuran.

Menurut Kementrian pendidikan dan kebudayaan (2017), Terdapat lima nilai karakter utama yang bersumber dari Pancasila, yang menjadi prioritas pengembangan gerakan PPK; yaitu religius, nasionalisme, integritas, kemandirian dan kegotongroyongan. Nilai religius yang dilaksanakan oleh PKBM Aditya yakni dengan menerapkan kebiasaan untuk beribadah tepat waktu. Untuk membentuk sikap nasionalisme, PKBM Aditya rutin mengadakan kegiatan agustusan setiap tahun nya dan juga memiliki kegiatan ekstrakurikuler unggulan yakni pramuka. Untuk mencapai nilai integritas, PKBM Aditya memiliki aturan tata tertib yang harus dipatuhi siswa. Seperti budaya disiplin datang tepat waktu sebelum jam pelajaran dimulai. Dan rata-rata siswa disana sudah datang sebelum waktu yang ditentukan, Bentuk kemandirian siswa terlihat pada saat tutor memberikan sebuah tugas, para siswa langsung sigap untuk melaksanakan/mengerjakan nya. Kegiatan gotong royong yang dilakukan siswa terlihat pada saat mereka berdiskusi kelompok, mereka saling berdiskusi untuk menemukan jawaban atau memecahkan suatu masalah.

Menurut Wina Sanjaya (2010:197) “Terdapat beberapa faktor yang dapat mempengaruhi kegiatan proses sistem pembelajaran diantaranya faktor guru, faktor siswa, sarana, alat dan media yang tersedia, serta faktor lingkungan. Adanya semangat motivasi dari dalam diri siswauntuk menjadi pribadi yang baik. seperti misal padasaat sebelum memulai kegiatan pembelajaran antusiasme terlihat pada saat akan memasuki kelas mereka berbondong-bondong mengantri satu sama lain untuk masuk kedalam ruangkelas,kelayakan kualitas sarana dan prasarana yang PKBM Aditya miliki menjadi salah satu faktor yang dapat menunjang proses belajar, karena mulai dari media belajar, kualitas dari fasilitas belajar hingga kenyamanan tempat belajar yang diberikan oleh pihak lembaga dapat menunjang proses belajar agar dapat sesuai dengan tujuan yang telah ditetapkan. apabila sarana dan prasarana yang ada tidak memadai maka kegiatan belajar pun akan terhambat. para tutor dapat mengindentifikasi karakteristik kebutuhan setiap siswa, serta dapat membantu para siswa agar menjadi pribadi yang lebih baik, Dalam segi penguasaan materi dan pengajaran nyapun sangat mumpuni, setiap bulan nya mereka di bekali dengan workshop atau seminar yang di sediakan oleh penyelenggara, tutor memberikan teladan yang baik kepadasiswa, Tutor di PKBM Aditya dapat bergaul secara efektif dengan para siswa, Kondisi lingkungan di PKBM Aditya cukup baik.

\section{KESIMPULAN}

Proses pembelajaran pendidikan karakterdi PKBM Aditya di dasari oleh ingin nyamenciptakan generasi yang baik dari segi sikap dan perilaku yang dapat menjadi pembeda dengan yang lain nya. Dalam proses nya, PKBM Aditya membuat perencanaan pendidikan 
karakter dengan memasukkan nya kedalam modul pembelajaran silabus/rpp. Nilai karakter yang paling diutamakan pun yaitu religius, disiplin, kreatif, toleransi. Adapun bahan ajar yang disediakan oleh PKBM Aditya terdiri dari beberapa sumber salah satunya buku kejar paket c yang disediakan oleh dinas pendidikan. Dalam melaksanakan penanaman nilai-nilai karakter, tutor di PKBM AdityaKarawang sudah melaksanakan nyadengan baik. Mereka melakukan kegiatan pembelajaran semaksimal mungkin agar siswa tidak hanya memiliki pengetahuan tentang materi yang disampaikan namun juga mampu mengimplementasikan nilai-nilai karakter yang sudah diberikan. Tutor menggunakan berbagai metode dengan tujuan siswa paham dengan materi yang disampaikan. Untuk tahap evaluasi nya sendiri berlangsung pada saat pembelajaran dimulai hingga selesai nya pembelajaran dengan pengamatan langsung.

Dalam pengimplementasian nilai karakter yang wajib ada di setiap Lembaga menurut kementrian pendidikan nasional ada lima yaitu religius, nasionalisme, integritas, kemandirian dan kegotongroyongan. Nilai religius, nilai religius yang terdapat di PKBM Aditya lebih mencodongkan kepada sikap rajin beribadah. Nilai nasionalisme yang ada di PKBM Aditya yaitu dengan mengadakan kegiatan kebangsaan setiap tahun nya seperti agustusan. Nilai integritas yang ada yaitu dengan menerapkan pola budaya datang tepat waktu sebelum dimulai nya kegiatan pembelajaran. Nilai kemandirian terlihat pada saat siswa mengerjakan tugas pelajaran dikelas. Nilai gotong royong pun terjadi pada saat pembelajaran seperti para siswa saling berdiskusi untuk bersama-sama menemukan/menjawab soal yang telah diberikan oleh tutor.

Faktor pendukung dan penghambat yang terdapat di PKBM Aditya adalah Adanya semangat dan motivasi yang kuat dari para siswa agar bisa menjadi lulusan yang berkualitas. Sarana dan prasarana yang layak dan cukup lengkap untuk menunjang kegiatan pembelajaran. Para tutor pun sudah mampu menguasai materi dan dapat membaur secara aktif kepada siswa. Untuk faktor penghambatnya yakni adanya gangguan pengaruh negatif dari beberapa siswa, kurangnyakordinasi dari beberapaorangtua siswamembuat penerapan karakter agak terhambat karena tidak semua orangtua dapat memantau langsung anaknya dirumah.

\section{DAFTAR RUJUKAN}

Hamalik, O. (2003). Kurikulum Dan Pembelajaran, Jakarta: Bumi Aksara.

Hamalik (2008). "Efektifitas Pembelajaran Matematika Melalui Metode Aritmatika Terhadap Ketuntasan Belajar Kelas 1 SDN Sindangwangi 1 Tahun 2016”. Jurnal Elementaria Edukasi Volume 1 No 1 Tahun 2018.

Kamil, Mustofa. (2011). Pendidikan Non Formal, Bandung: Alfabeta.

Sanjaya, Wina. (2010). Strategi Pembelajaran Berorientasi standar proses pendidikan. Jakarta: Kencana.

Sihombing. (2001). "Eksistensi Pusat Kegiatan Belajar Masyarakat Berbasis Sumber Daya Lokal Dalam Pembangunan Pendidikan".

Sudjana, Djuju. (2014). Evaluasi Program Pendidikan Luar Sekolah. Bandung: Remaja Rosdakarya.

Sutikno. (2014). "Efektifitaas Penggunaan Metode Pembelajaran Diskusi Kelas Dengan Strategi Tps Untuk Meningkatkan Motivasi Belajar". Jurnal Ilmiah Sekolah Dasar Volume 3, Number 3, Tahun 2019.

Sugiyono. (2013). Metode Penelitian Kuantitatif, Kualitatif dan R\&D. Bandung: Alfabeta. Zubaedi. (2013). Jurnal Kependidikan "Penguatan Pendidikan Karakter". 